\title{
4 Zanele Muholi's work as decolonisation and political communication
}

\author{
Beschara Karam
}

\section{Introduction}

Everything about Muholi's art is political: the portraits, the recording of testimonies, the photographing of trauma, as well as the representation of contexts, the lived realities, and the apartheid/colonial histories which she depicts. As Muholi (cited in Abel-Hirsch 2020) has stated, 'I use my own body and face because the work is meant to be confrontational, both personal and political at the same time' and

Race, class and privilege are intimately connected to wealth, access and exclusion. The world of art is not isolated from all of this - it is informed by the time it is in as well as the context in which it operates and continues to operate.

Muholi questions what it means to be an "artivist" (Goldsmid \& Muholi 2010) in the repressive, violent socio-political context from which they was born and grew up in - the height of apartheid. Where her mother served a White family for more than 40 years. She challenges the massive gap between the South African legislation and lived realities. Muholi wants to reclaim of the lives of Black and trans queers living in South Africa. She chooses to represent, challenge, and memorialise the enduring legacy of apartheid and colonialism which continue to affect the lives of the Black LGBTQIA+ South Africans. Muholi is responding by making the invisible visible, depicting the unrepresentable, in a political landscape that still favours White lives over Black lives. Muholi does this through her combined artistic and community engagement work. Zanele Muholi's ${ }^{1}$ film Difficult Love (Goldsmid \& Muholi 2020) reactivates memory as a way of negotiating the present, to generate a historical and political consciousness, where the evidence of recording testimony is not necessarily to preserve history for posterity but to 'tell their stories to the public, to be listened to, and to be acknowledged' (Goldsmid \& Muholi 2010). Their body of work disrupts and challenges politics and gender: the heteropatriarchal, colonial and post-colonial gaze; apartheid and its legacies. For instance, 
not only is Difficult Love a "site of memory" or an artefact of memory, wherein individuals not only recount their traumatic experiences, but a political act as it documents Muholi's work in local communities. For example, Muholi takes in groups from their community to view their works, exhibited in museums or art galleries: the gallery becomes a structure of memorialisation wherein their works engage both the individual and the community both separately and mutually in a process of conversation and discourse - displacing and challenging the reification and gentrification of such spaces. But more importantly it serves as a form of political intervention: giving the marginalised a view into a "privileged" geographical and mental place, thereby decolonising it and de-reifying it. In addition, the film documents how they give cameras to disenfranchised subalterns (lesbians and trans, most especially). Muholi teaches them how to use a camera and then prints their photographs. Once again, Muholi has taken a very gentrified and elitist art form and decolonised it, making it accessible, but most significantly, allowing the photographs to tell a story(ies). Muholi and Goldsmid's film, Muholi's community engagement projects, and their own photographic works are significant in that they raise social and historical consciousness to examine cultural issues of experience, traumatas, memory(ies), sexualit(ies), identity, colonialism, apartheid, heteropatriarchy, and representation. With themes of power, subjugation, violence, femicide, and corrective rape. Goldsmid and Muholi's (2010) film and Muholi's photographs are a unique "politics of perception" (Wallis \& Duggan 2011:2) and they help render accessible the shattered experiences of lesbians and trans' post-memories, traumatas, apartheid, post/colonialism, and history. Thus, in this chapter I argue that Muholi's works are therefore a form of political communication and serve as examples of disruptive performance and decolonisation. As I understand it, the underlining ethos of decolonialisation has two essential tenets: humanity and social justice. So too does the work of artivist Muholi. In addition, their works document political issues which, through their art and activism, they communicate to the audience and communities, communicating about politics: gender, poverty, and, class in a South African post-apartheid landscape. This chapter will make use of Paolo Freire's work as well as that of bell hooks to support the argument. The chapter also looks at secondary witnessing and historical trauma, and the role Muholi's work plays in representing, memorialising, and sharing these traumas. The chapter only focuses on their film Difficult Love; although the film itself references much of Muholi's varied and insightful works, as well as their activism.

\section{The film: Difficult Love (2010)}

Difficult Love was produced by Peter Goldsmid and co-directed by Zanele Muholi and Peter Goldsmid. It was commissioned by the South African Broadcasting Corporation (henceforth, SABC) ${ }^{2}$ in 2010. Peter Goldsmid, 
an award-winning film and television director and producer, has worked with both SABC 1 and SABC 2; and he is most well known for his television series Justice for All (1999-2006), Glas-kasteel (1993), and Riemvasmaak (2008). His critically acclaimed film directorial debut was The Road to Mecca (1991), starring Academy Award winner Kathy Bates. Although both Muholi and Goldsmid co-direct this film, and technically this is their film, the film really is about Muholi - their works, their identity, and their history, as they state in the very beginning: "this is me, presenting myself". Difficult Love has been screened at many film festivals around the world, including the International Film Festival on Human Rights in late 2013, and it has won several awards. ${ }^{3}$

The film is a comprehensive compilation not only of Muholi's work but also of the issues and controversies that have surrounded their work. It is, from the outset, in and of itself, a form of activism: beginning with a photoplay of Muholi's photographs and their introduction of theirself to the viewer as an "artivist", or gender activist, first and foremost. Muholi defines their own photography as "radical and political" (Goldsmid \& Muholi 2010). The film not only documents Muholi's work and that of some of their subjects, but also presents the viewer with the overt connotations of their work: a challenge to patriarchy, heteronormativity, the nuclear family, trauma, memorialisation, historical consciousness and colonialism. Difficult Love also challenges. The film focuses on Muholi's own identity as Black, lesbian but also their identity as ballroom dancer, sister, "grandmother", partner, tomboy, beauty pageant contestant, and photographer. Muholi is unbearably sad when talking of the passing of their mother. What is of particular interest is that no-where is their father ever mentioned.

At a secondary level, are the more insidious themes that this documentary contests and exposes: issues of race, poverty and homelessness, the wounds and scars of apartheid, class, and even visual illiteracy. The film offers a socio-economic and ideological critique of South Africa.

Muholi's erudite deconstruction of their own work, as well as their own identity is thought-provoking. One of the most stunning set of photographs (triptych) is the image of Muholi lying with their ex-partner on top of Muholi, from their series Caitlin \& I (2009). Muholi describes the photograph as one of racist ideology and slavery: they put their ex-partner on top of them because according to Muholi, 'we feel like slaves in our relationships' (Goldsmid \& Muholi 2010). However, it does raise an interesting observation of Muholi's work: most photographers let their works speak for themselves. They leave the viewer to interpret the photographs, often presented in sparse exhibitions. Not so with Muholi. From the very outset of this documentary, Muholi is always at great pains to explain the context and background of their work.

Some of the photographic and community activism that features within Difficult Love includes Trans(figures) (2010-2011) (transgender individuals in various poses) and Ordeal (2003) (a close-up black-and-white figure 
wringing out a cloth from an enamel basin). The implication, from the title of the photograph, is that the individual is washing herself after a traumatic event. Caitlin \& I (2009): Muholi and their ex-girlfriend, Caitlin. A triptych depicting Caitlin on top of Muholi facing towards the ceiling, while Muholi lies of her arms, bed downwards. Both appear completely naked. Faces and Phases (2006-ongoing): Black and White portraiture series. Where individuals' diverse identities and individualities are central: close-up portraits of Black lesbians, transgender, and gender non-conforming individuals (from South Africa and elsewhere). In this series, sometimes a portrait is accompanied by the testimony of the individual in the portrait: documenting and archiving the social and sexual injustices they have endured. Thus, providing historical, political, and personal context of those photographed for history and memorialisation. The participants stare directly into the camera lens. This series is dedicated to Muholi's friend, Ms Busisiwe Sigasa (an activist, and poet, who died at the age of 25 from AIDS-related health complications, which she contracted after being correctively raped). For me, the title of her series "Faces" refers to the individuals faces - their stance, expressions dress - while "Phases" indicates a "transition" of gender and sexuality - from being unrepresentable to being representable, transitioning from being invisible to being visible, from being unheard to being heard (where testimony accompanies the portrait), from being unworthy to being worthy. I believe these portraits represent a pride, and an acknowledgement of their beings, their socio-political realities, their lived realities, their different contexts, and the fact that they matter. 'Collectively, the portraits become an act of visual activism, the photographer's response to the violation, rape and murder or innocents because of their sexualities and ethnicities'(Brodie/Stevenson curatorial notes 2009). Aftermath (2004): a close-up of a Black woman, from the waist to just above the knees. Wearing Jockey underpants, hands folded in front of her pudenda, with her right thigh covered in a massive scar, from where a wound has been inflicted and sewed up, the stitches leaving dotted, raised scars on either side of the thighlength slash. The scars, as well as the protective hands, speaks of trauma, of strength (survival) and sensitivity (in the intimate portrayal of the hands protecting her sex(uality)). Being (2008) depicts Black South African lesbian couples and their domestic lives. Massa and Mina $(h)$ (2008) shows a photographic project that is based on the life of Muholi's mother who worked as a domestic worker for the same family for 42 years. The colour photographs feature Muholi: sometimes as the "maid" and sometimes as the "madam", in different domestic scenes. Muholi role plays within it. Muholi has said that this series is meant to acknowledge domestic workers wherever they may be (Brodie/Stevenson curatorial notes 2009).

The community engagement work that features is "Ikanyiso" (2009) (meaning "illuminate" in Zulu), which is a non-profit organisation whereby Muholi trains individuals to photograph and print their images, a form of queer visual activism - the teaching of visual literacy. ${ }^{4}$ The film also 
mentions Forum for the Empowerment of Women (FEW), which Muholi co-founded in 2002: a safe space and place for Black women to meet and organise their political and social activism.

\section{Decolonial studies/decolonisation}

The seminal authors of decoloniality - Ramón Grosfoguel (2011), Enrique Dussel (1977), Aníbal Quijano (1991, 2000), and Walter Mignolo (1995, 2000) - are writing about the 'subalternalized racial/ethnic/sexual spaces and bodies' (Grosfoguel 2011:2; cf. Grosfoguel 2007). In doing so, they have highlighted that South Africa, as a post-colonial country, is still heteropatriarchal capitalist, hierarchical, racialised, classist, gentrified, and imperialist (Ndlovu-Gatsheni 2013). South Africa is still entrenched with insidious colonial, institutional power interactions and entanglements. It is thus essential that such scholars, as well as various contemporary cultural texts, challenge this "colonial power matrix" (Quijano 1991, 2000). This power matrix includes reified gender hierarchies, local racialised divisions of class and labour, aesthetic hierarchies, and epistemic hierarchies that preface, or privilege, White over Black. Academic Quijano expounds on his concept by expressing that it is also an "organising principle" that involves exploitation and domination (1991). Furthermore, his concept is intrinsic to politics, socio-economics, institutions, and even epistemologically (Quijano 1991, 2000). This "colonial power matrix" ("patron de poder colonial") or "coloniality of power" is still intrinsic to South Africa. The film, Difficult Love, challenges this "colonial power matrix", by providing a reflexive "decolonial critique" that acknowledges the silenced, marginalised, and subalternised (most especially the victims of homophobia and transphobia, poverty and social engineering). Difficult Love questions the "colonial power matrix" that permeates South Africa at every level by screening the continued apartheid of class, gender, and economics.

\section{bell hooks}

Drawing on the work of bell hooks (1995), Art on My Mind: Visual Politics, this chapter positions Difficult Love as a film that 'constitutes one of the rare locations where acts of transcendence can take place and have a wide-ranging transformative impact' (1995:8). As such, this film is a revolution in viewing:

we struggle against forces of domination and move toward the invention of the decolonized self, we must set our imaginations free. Acknowledging that we have been and are colonized both in our minds and in our imaginations, we begin to understand the need for promoting and celebrating creative expression. 
This film and the works of Muholi cited within, along with testimonials, are indeed a critical "intervention": they are sites of visual contestation; cinematic and photographic aesthetics, with personal (subaltern) narratives that re-remember; they reclaim history(ies), ancestry(ies), and identity(ies). In doing so, the film and the artwork it references decolonises both the mind and the imagination: asking the audience to transcend gender, politics, and socio-economics. Muholi's collective works have motifs of queerness, history and ancestry (Muholi's own and that of South Africa), memory, trauma, colonisation, feminism, masculinity, trans, identity, and apartheid (and post-apartheid). Muholi's film and art transcend and transgress the boundaries of what bell hooks terms "visual politics" (1995:4), which include race, culture, and gender. In doing so, this collective artwork and film help set our imaginations free: they are self-reflexive, and they offer different ways of seeing and imagining the past, the present, and the future. For instance in the series Massa and Mina(h), Muholi's role plays between madam and domestic worker: an effort to reimagine the past, what it was like being a domestic worker under apartheid, as her mother was. And re-imagining what it is like to be a domestic worker now: a White domestic worker working for a Black madam.

bell hooks also argues that not only visual aesthetics, in this case the photographs and film, are a site of contestation and struggle, but they collectively "nurture the spirit and provide ways of rethinking and healing psychic wounds inflicted by assault from the forces of imperialist, racist, and sexist domination' (1995:4-5). For example, the photographic series Massa and Mina(h) addresses psychic and historical wounds - rethinking and re-imagining (colonial) history but also the physical and psychical wounds of everyday subjugation; lack of independence. Being a domestic worker during apartheid meant having to abide by the policies of the nationalist government, such as the Pass Laws and social engineering. Only one Black person was allowed to stay at a White domicile at any one time, after curfew. This meant that Black mothers who worked as domestic workers had to leave their own children to be raised in the community, or an extended family, and they rarely saw their own children. While simultaneously raising the White children of the family they were working for. Muholi also addresses physical and psychical wounds by directly inhabiting the spaces and contexts of the subalterns, the lesbians and trans individuals who have no homes or livelihoods, which, while they attest is the result of an inherited violence of apartheid, shows no sight of change in the "new" dispensation, the so-called post-apartheid era. I refer here to the project where Muholi gives cameras and photography lessons to individuals in the communities (townships in most cases but also make-shift "communities" of shacks; and even those who are homeless, such as the couple who live under a bridge). Here, Muholi not only teaches a skill, but encourages individuals to see themselves (through the lens of the camera) as worthwhile and to have some sense of self-esteem. Most especially those who have suffered from aggressive 
patriarchy and sex crimes for their queerness. Muholi also encourages them to acknowledge that they belong, and they have a right to existence. While Muholi's documented project is empowering, the result is a community(ies) and individuals who have to confront their pain, and physical and psychical traumata as a direct result of both colonial and post-colonial violence. Whether it be corrective rape, thrown out of the home for "coming out", or losing their livelihood for being gay.

Through several motifs, the themes of established power and authority are explored by Muholi, both literally and obliquely. These are the political, social, economic, and gender motifs. The film, thus, challenges the status quo, and disrupts it as a form of "epistemic disobedience" (Mignolo 2011). The film, and Muholi, strongly suggests that a destabilisation or epistemic disobedience of the status quo is called for: a decolonisation of the mind. The film and the photographs therefore work as a site of possibility, and an agent of change, but the socio-realities of those living with alternative sexual and gender lives are devastating to watch, despite Muholi giving the individuals a voice/s.

Returning to bell hooks, hooks also refers to the 'representation as a location of contestation' (1995:4). Keeping Muholi's film and photographs in mind, "contestation" relates to the contesting of colonial and apartheid history and post-colonial and post-apartheid contexts. In other words, Muholi questions why things have not yet changed for the majority of Black lives, with the "new" government. Why are the violence, patriarchy, and sociorealities of the subalterns unchanging? However, representation is also a way to decolonise the mind and the imagination by re-imagining, reclaiming, and remembering (worlds and identities of multiverses). And so not only does Muholi give "life" to these stories; they claim them for eternity, as is the nature of photography, but they encourage the audience to engage with these stories and motifs. Muholi wants us, the audience, to imagine a world without rape, misogyny, queericide, but also one where a country and a community are truly post-colonial and the legacies of our haunted histories have been banished. Where policies of the government for freedom of sexual expression are upheld and enforced.

Another element of decolonisation to be considered when viewing Difficult Love is that of context. Where the lived realities and experiences of different individuals are acknowledged and where empathy is reflected. Both are prevalent in the film which emphasises the context, identities, and socio-political realities of diverse cultures: and is ultimately a rallying cry for empathy, compassion, social justice, and inclusion.

bell hooks also writes that 'representation is a crucial location of struggle for any exploited and oppressed people asserting subjectivity and decolonization of the mind' (1995:3). For Muholi, film and, by extension, photography are encounters with the visual that bear witness to, and work to signify and depict 'the silence and erasures of the past' (1995:3). Again, this speaks to Muholi's interrogation of both the past and the present. Muholi also 
bears witness to different traumas as a result of patriarchy and misogyny, and they demand the recognition of the realities of the present: the inherited legacies of the past that haunt the present. Consider, for example, White lesbians who have the freedom to enact their lives in the open if they so choose to without the fear of corrective rape or brutal beatings. Unlike their equivalents in Black communities, where to "come out" is to invite violence and even death. This is not to say that White lesbians live without any discrimination, but it is a rarity, and if it is the case, they have legal recourse, if they so choose, whereas their Black counterparts cannot afford such remedies in the majority of cases.

The film also bears witness to the apartheid and colonial and political history and memory of African identity and culture. Included here are motifs of the perpetuation of imperialist socio-political powers and physical structures. For instance, Muholi visits the home where their mother worked as a domestic worker in a middle-class White area (evidence of apartheid's social engineering). Muholi seems so fond of the family which patronised them. Muholi, interestingly, feels no anger towards the patronage and is very grateful to that family. Even the fact that Muholi includes them in this very personal film and narrative of theirs is testament to a (shared) fondness. After all, Muholi tends to exclude their father completely. Revisiting the family their mother worked for does bring up the past: how Whites often took it upon themselves to purchase school uniforms and books for the children of their domestic workers. (Although this shows a kindness, domestic workers worked without any rights or unions and were at the mercy of their employers.) So too was in the case of Muholi and their "second" White family.

\section{Paolo Freire}

Now we turn to the work of Paolo Freire and his idea of "consciousness raising" (1970), or critical consciousness, or "conscientization" (conscientização), which is the noting/uncovering of social and political contradictions and acting against oppression.

This concept is used here in order to understand and explain how cinema has the potential to develop, provide, and facilitate political expression: that film politicises consciousness, and while I argue here that Difficult Love also politicises thought, it encourages a political consciousness. In that it raises questions not only about the inheritance of apartheid but also about our current government: for example, why, when South Africa has the most progressive constitution, ${ }^{5}$ is there a conspiracy of silence surrounding corrective rape and violence against lesbians in the Black community (van der Schyff 2015, 2018)? As one man says in the film Difficult Love "rape is rape" it does not matter if that woman is a lesbian or not. But it does matter. Why, in one of the most democratic countries in the world, is "corrective rape" considered to be a purely South African phenomenon? (Wood 2013:297). Not only does the film, and Muholi's photographs represented within, raise 
a "political consciousness" about violence against women, most especially Black women, lesbians and trans, but also about apartheid and colonialism. Julia Kristeva (2002:435) writes of history: 'What makes sense today is not the future... but revolt: that is, the questioning and displacement of the past. The future, if it exists, depends on it'. Muholi challenges the past by questioning apartheid's classist and imperialist legacies, and the "new" government. Difficult Love also challenges the conspiracy of silence about corrective rape; we see this when the community gets together to speak about their concerns, interviewee Funeka Soldaat features. They were brutally raped and stabbed a total of 11 times: those who are "correctively" raped choose not to report it as they would be accused of "lying". Two of Muholi's comments bear repeating: "the wounds of the past keep on opening" and "I'm breaking". Muholi's film, her photographic series, raises consciousness not only about political and social justice but also about traumata, which brings us to the concept of "secondary trauma".

\section{Secondary trauma}

In her book Unclaimed Experience: Trauma, Narrative, and History (1996:11), Cathy Caruth argues that a textualist approach (one which insists that all reference is indirect) can afford us unique access to history:

Through the notion of trauma... we can understand that a rethinking of reference is aimed not at eliminating history but at resituating it in our understanding, that is, at precisely permitting history to arise where immediate understanding may not.

It is therefore important to represent trauma, as Muholi does. Caruth also argues that history as being inherently traumatic, and trauma as an overwhelming experience that resists integration and expression. No one can deny that apartheid and colonial histories are not written with trauma. And the legacies of those traumas are still present today. Furthermore, according to Caruth, conjoining a Freudian view of trauma with a deconstructive "vigilance" regarding the indeterminacies of representation in the analysis of filmic and photographic texts that bear witness to traumatic histories can grant us an insightful mode of access to extreme and "unrepresentable" events and experiences that challenge both understanding and representation. Caruth adds that 'history, like trauma, is never simply one's own, ... history is precisely the way we are implicated in each other's traumas' (1996:24). In a catastrophic colonial, or so-called post-colonial) age such as ours, Caruth writes elsewhere, 'trauma itself may provide the very link between cultures' (Caruth 1995:11). With trauma forming a bridge between disparate historical experiences, so the argument goes, listening to the trauma of another can contribute to cross-cultural solidarity and to the creation of new forms of community. I would like to argue that it does, most especially 
where South Africa is concerned. Drawing from Caruth's theory, I now look at Muholi's work specifically as a documentary film that bears witness to the unrepresentable traumatic of those Black lesbians and trans individuals who have suffered psychologically, physically, or sadly lost their lives. My second exposition deals with Muholi's work as trauma art and an exemplification of "vicarious, or secondary, trauma". Cathy Caruth defined trauma in her seminal work, as 'an overwhelming experience of sudden or catastrophic events in which the response to the event [is] ... often delayed, uncontrolled [and] repetitive' (1996:11). While collective traumata are those traumata experienced as a group, community, or culture. Apartheid and colonisation, homophobia, transphobia are traumatas experienced by both the individual and the collective. Near the beginning of the film, Muholi films two women, Petra and Praline, who were thrown out of a homeless shelter because of their love for one another, and are now living under a bridge in horrendous conditions. Muholi states that they wish they could do more for them, they start to cry. Later on, towards the end of the film, another visibly tearful Muholi says, after screening photographs from their 2004 Aftermath exhibition are shown, which feature lesbians who have been raped and beaten, that they no longer wish to photograph the violence, or the aftermath of violence, and only wish to photograph "love". Muholi switches to their mother tongue and says: "I am hurting inside". With those two scenes from Difficult Love, it seems apparent to me that Muholi is experiencing secondary trauma. Secondary witnessing and secondary trauma was conceptualised by Marianne Hirsch (2003:9), whereby her "performative memory work" and her concept of "postmemory" emerged from an attempt to describe the

relationship of children of survivors of cultural or collective trauma to the experiences of their parents, experiences they 'remember' only as the narratives and images with which they grew up, but they are so powerful, so monumental, as to constitute memories in their own right.

Initially, her term "postmemory", coined in 1997, was an attempt to understand and account for a "familial inheritance" of memories for secondgeneration Holocaust survivors. Since then, Hirsch as well as other authors, such as James E Young (2018), Joshua Hirsch (2004), and Shoshana Felman (2001), has taken the term and 'broadened its application to a more general, cultural inheritance that can transcend ethnic or national boundaries' (cited in Hirsch 2003:9-10; cf. 2012). Postmemory is therefore "defined through an identification with the victim or witness of trauma, modulated by an unbridgeable distance that separates" the two. Postmemory is thus

retrospective witnessing by adoption - it is a question of adopting the traumatic experiences - and thus also the memories - of others as experiences one might oneself have had.

(Hirsch 2003:10, my emphasis) 
Hirsch privileges photographs as the affective prop or artefact by which traumatic memory is transmitted. It is a vicarious witnessing of 'seeing through another's eyes, of remembering through another's memories' (Hirsch 2003:10) that is so apparent in understanding Muholi's film and photographic works. Muholi's photographs provoke a vicarious and postmemorial witnessing of loss, a secondary trauma. Andreas Huyssen (1995:15) argues that these cultural artefacts or memory works open up an interpretive space around the artefact. No matter how "mediated and contaminated in the eye of the beholder", such artefacts have 'a surplus of meaning that exceeds set ideological boundaries, opening spaces for reflection and counterhegemonic memory' (Huyssen 1995:15): Muholi's works are considered to be "counter-hegemonic memory" not only with regard to history or politics but also, and most importantly, with regard to heteronormativity and Black lesbianism and trans.

One of the main reasons for Hirsch to coin the term "postmemory" had to do directly with representation of the unrepresentable. The purists or conservatives argue that only those who have experienced a trauma or atrocity first-hand, either as witness or as victim, are allowed to represent it. Of course, the problem with that is that most individuals who have been traumatised are not artists or writers or film makers. How then does one account for those artists who are able to convey such trauma with authenticity and integrity?

Postmemory is a powerful and very particular form of memory precisely because its connection to its object or source is mediated not through recollection but through imagination...

(Hirsch 1997)

Through "postmemory", a theory through which Hirsch argues that an individual can represent the horrors of war, genocide, and rape through identification, empathy, and imagination. In Muholi's art, there is all three.

Joshua Hirsch (2004) also views film as "vicarious trauma"; he adds to the trauma discourse by suggesting that after watching visual representations or visual recordings of trauma, the viewer often displays similar symptoms of trauma through the vicarious reliving of the traumatic experience. Even worse, those who encounter or watch many instances of such vicarious trauma themselves face the possibility of experiencing post-traumatic stress. E Anne Kaplan (2013:54) supports Hirsch's argument that individuals are vicariously traumatised: by that they mean that individuals suffer effects similar to trauma by watching the trauma of others. Traumatic memory, in its belatedness, involves a type of forgetting: victim-collectives or nations may also "forget" through a process of traumatic amnesia. Meanwhile, the discourse of those who do remember is often stifled or silenced: giving rise to conspiracy of silence. This includes viewing national traumas, such as the genocide in Rwanda represented in the films Hotel Rwanda and 
Shooting Dogs; or the ethnic cleansing of the Bosnian War, depicted in the film Savior and In the Land of Blood and Honey. It has taken almost 20 years before films about these national traumas were made. The same goes for the Holocaust and the Vietnam War. This is the significance of Difficult Love: it challenges the conspiracy of silence and documents the narratives of traumatised Black lesbians.

Muholi's photographs as well as this film reinforce Cathy Caruth's assertion in her book Unclaimed Experience that 'history [is] the history of trauma' (1996:10). As W G Sebald writes in his book Austerlitz (2001:16), 'the marks of pain ... trace countless fine lines through history', this refers not only to apartheid but to the history of atrocities perpetuated against lesbians - their history or histories. Cathy Caruth, one of the leading scholars in trauma studies, emphasises (1996:8):

the way in which one's own trauma is tied up with the trauma of another, the way in which trauma may lead, therefore, to the encounter with another, through the very possibility and surprise of listening to another's wound.

Muholi's film and works are a confrontation with South Africa's modern political democratic history as trauma, to challenge and to affect change; as well as to extinguish the phantoms that haunt contemporary post-apartheid society: they attempt to right the wrongs of apartheid - through bringing the community to galleries exhibiting their work and installations, through teaching those who are disenfranchised both visual literacy and photography. This film unveils actual horror and focuses on the displaced lives that gesture towards this horror.

W G Sebald, who grew up in Germany during the Second World War, also wrote that 'certain painters and philosophers who seek to penetrate the darkness which surrounds us, purely by means of looking and thinking' (2001:3-4): this too is an accurate definition of Muholi's works and film. She uses the film to point out the "darkness" of poverty, misogyny, grievous bodily harm, corrective rape, and exclusion in existence in South Africa.

Muholi's photographs, and most especially this film, seem predicated on Caruth's insight that the language of trauma and its repetition of suffering require a special mode of reading and listening a shared intimacy. This encounter with another's wound or traumata allows for the acknowledgement of another's wound. This witnessing of another's wound reflects history, both personal and collective: apartheid as well as rape and violence. Caruth's conception of trauma: 'that the most direct seeing of a violent event may occur as an absolute inability to know it' (1996:92), but a mediated viewing, such as through Muholi's works, ensures an ability to know and recognise it. That is the role of post-memorial trauma art, and the role of Muholi's works.

Jill Bennett in her book Empathic Vision: Affect, Trauma and Contemporary Art, published in 2005, argues that art has "unique capacities" to 
trigger an empathic response (cf. Luckhurst 2003, 2008) from the viewer that should not be an end in itself, but rather should lead to critical thought. This affective power of art is most especially found in the case where art draws from trauma, which as Caruth (1996) and Hirsch (2004) have argued, is traditionally defined as both beyond language and representation. Bennett argues that the visual arts are generative rather than simply representational. This too encapsulates Muholi's oeuvre: their works are not simply representational, but they are affective, and they offer a socio-economic and political critique as well as a sexual critique. Following on from secondary trauma is that of memorialisation.

\section{Memorialisation}

Muholi's works are a form of memorialisation. Memory and trauma studies have addressed how forms of memorialisation might transmit a cultural memory of trauma to those who did not witness the event first-hand. In the past century or so, activities of collective remembrance, or memorialisation, have proliferated. It takes several different forms from museums, memorials, art works, literature, street theatre, and ceremonies. It is a social act and an 'embodiment of the cultural act of memory and remembering' (Mhando \& Tomaselli 2009:34). Memorialisation can be understood as the practice whereby individuals, communities, and societies interact at sites of symbolically represented memory, deriving from and impressing on an item or act 'about specific times, places, persons and events laden with affective meaning' (Mhando and Tomaselli 2009:34). Memorialisation is viewed as a "search for meaning" through performance or enactment; memorials are "sites of memory" which encapsulate themes of catharsis, absence, loss, and remembering. Pierre Nora, a French social historian, claims that "lieux de mémoire" or "sites of memory" are monuments, museums, festivals, and even archives that document history (1989). He claims that these historical artefacts are essential to remembering histories that have been abandoned.

A "site of memory" or "lieux de mémoire" as defined and conceptualised by Pierre Nora (1989) can be seen as 'an active practice of remembering which takes an inquiring attitude toward the past and the activity of its (re) construction through memory ... undercutting assumptions about the transparency or the authenticity of what is remembered' (1989) and 'such sites of memory are always dynamic' (Mhondo \& Tomaselli 2009:35). Difficult Love reactivates memory as a way of negotiating the present, to generate a historical consciousness, where the evidence of recording testimony is not necessarily to preserve history for posterity but to 'tell their stories to the public, to be listened to, and to be acknowledged' (Mhondo \& Tomaselli 2009:35). Not only is Difficult Love a "site of memory" or an artefact of memory, wherein individuals recount not only their traumatic experiences, but $\mathrm{Mu}$ holi's exhibitions, where Muholi takes in groups of community youths from their community to view their works; these too are "sites of memory": the 
gallery becomes a structure of memorialisation wherein their works engage both the individual and the community separately and mutually in a process of conversation and discourse. Their film and photographic works are significant in that they raise political, social and historical consciousness.

As James E Young (2018) puts it, cultural artefacts articulate a loss, they articulate a void, and they present an absence. For Young, we can never really understand the unrepresentable; however, the best way to engage with such a dilemma is to look at their representations. For Muholi, this is especially true: in a brief column that they wrote about Faces and Phases exhibition, some of these photographs appear in this film, they stated that many of their models have died since they took their photographs. It is this sense of overwhelming loss that is provoked in those who view these cultural artefacts or memorials, or "memory works", such as art, architecture, films, and photographs; it is a sense of shock, something akin to trauma. As Young argues, it is a sense of shock that provokes remembrance of things not witnessed: a vicarious or secondary witnessing. And once again we are back to trauma and memory studies. These photographs are used as conduits of trauma to transmit traumatic memories. The more recent theoretical work of trauma and memory is underpinned by a concern that traumata must be shared. In Difficult Love we have both: Muholi's secondary witnessing, their photographs from their Aftemath series; as well as the first-hand testimony of Millicent Gaiku. Through this film all of these traumata become shared trauma.

\section{Conclusion}

In concluding, I quote Fariba Derakshani (Humbane 2014) in her keynote address at the opening of Muholi's exhibition Love and Loss, in February of 2014, held at the WITS Arts Museum in conjunction with the Stevenson Gallery, where they stated that Muholi was

a revolutionary who has had great impact in advocating and empowering black LBGTI communities of South Africa. Through her [sic] lenses, she $[s i c]$ has shot and offered a voice for black LGBTI stories which will live ahead of time in history.

This again is evidence that their work will not only be archival in nature, but a form of memory work, of memorialisation. Muholi has used their art as a lens to examine political and historical issues of experience, trauma, memory, the body, sexualit(ies), identity, and representation. Their film and photographs are a unique "politics of perception" (Wallis \& Duggan 2011:2), and they help render accessible the shattered experiences of politics, postmemory, trauma, lesbianism, apartheid, colonialism, and history. In concluding, this film and Muholi's photographs, in different but similar ways, incorporate themes of politics, colonialism, imperialism, reconstruction 
and reclamation of identity, subjectivity and lived realities (context(s) and multiverses); and most importantly it offers testimony. Not only Muholi's own personal stories but also those of the lesbian communities: the film and photographs become the "story-tellers"; they bear witness to political injustices, physical and psychological traumatas; and, as such, they argue for change, transformation, social justice, and reflection. Muholi is involved in participatory politics; she communicates about politics through her anticolonial lens and her community engagement projects. As Muholi (cited in Abel-Hirsch 2020) astutely states: 'My images are portraits, so if my work is being exhibited, someone else's existence is also being affirmed. What matters is having a dialogue - with people, with institutions and with history. It's a collective project of reclaiming space' and history. Thus, Muholi calls for the decolonisation of the mind and imagination, the raising of consciousness (of trauma), as well as the decolonisation of the politics of gender, colonialism, apartheid, and heteropatriarchy.

\section{Notes}

1 Muholi identifies as non-binary and therefore uses the pronoun they/them, as they have often stated, they identify as a human being.

2 The South African public broadcaster.

3 For example, the Lesbianism and Genre Award granted by the Equality, Cooperation and Citizenship Area of the Council of Bilbao in Spain.

4 Muholi has a similar project now, Women's Mobile Museum, 2018, with Lindeka Qampi: they create and mentor women in Philadelphia, using digital camera work; Photoshop; and even teaches them how to set up photography exhibitions and installations.

5 In 1996 South Africa became the first constitution in the world to outlaw discrimination based on sexual discrimination, and in 2006, it legalised same-sex marriage (Abel Hirsch 2020).

\section{References}

Abel-Hirsch, H. 2020. Zanele Muholi: Art and activism. British Journal of Photography. https://www.1854.photography/2020/07/zanele-muholi-art-and-activism/ http://archive.stevenson.info/exhibitionsbs/muholi/index.htm

Bennett, J. 2005. Empathic vision: Affect, trauma, and contemporary art. Palo Alto, CA: Stanford University Press.

Brodie/Stevenson Gallery. 2009. Zanele Muholi: Curatorial notes.

Caruth, C. ed. 1995. Trauma: Explorations in memory. Baltimore, MD: Johns Hopkins University Press.

Caruth, C. ed. 1996. Unclaimed experience: Trauma, narrative, and history. Baltimore, MD: Johns Hopkins University Press.

Dussel, E. 1977. Philosophy of liberation. Translated by A Martínez and C Morkovsky. New York: Orbis Books.

Goldsmid, P. \& Muholi, Z. (dir). 2010. Difficult love. [Film]. Johannesburg: South African Broadcasting Corporation. The entire film can be viewed for free at: https://www.imdb.com/video/vi3128728089 
Grosfoguel, R. 2011. Decolonizing post-colonial studies and paradigms of politicaleconomy: Transmodernity, decolonial thinking and global coloniality. Transmodernity: Journal of Peripheral Cultural Production of the Luso-Hispanic World 1(1): $1-38$.

Hirsch, J. 2004. After image, trauma and the Holocaust. Philadelphia: Temple University Press.

Hirsch, M. 2003. Mourning and postmemory. In The Holocaust. Theoretical readings, edited by N. Levi and M. Rothberg. Edinburgh: Edinburgh University Press Ltd., 416-422.

Hirsch, M. 2012. The generation of postmemory: Writing and visual culture after the Holocaust. Columbia: Columbia University Press.

hooks, b. 1995. Art on my mind. Visual politics. New York: The New press.

Humbane, A. 2014. "Black South African visual artist lesbian, Zanele Muholi, in a transparent coffin of love and loss". https://inkanyiso.org/2014/02/24/2014-feb14-black-south-african-visual-activist-lesbian-zanele-muholi-in-a-transparentcoffin-of-love-and-loss/

Huyssen, A. 1995. Twilight memories: Marking time in a culture of amnesia. London: Routledge.

Kaplan, E.A. 2005. Trauma culture: The politics of terror and loss in media and literature. New Brunswick, NJ and London: Rutgers University Press.

Kristeva, J. 2002. Intimate revolt: The future of the culture of revolt, the life of the mind and the species. In The portable Kristeva, edited by K Oliver. New York: Columbia University Press, 435-447.

Luckhurst, R. 2003. Traumaculture. New Formations 50(1): 28-47.

Luckhurst, R. 2008. The trauma question. London and New York: Routledge.

Nora, P. 1989. Between memory and history: "Les lieux de mémoire". Special Issue: memory and counter-memory. Representations 26(Spring): 7-25. https://doi. org/10.2307/2928520

Mhando, M. \& Tomaselli, K.G. 2009. Film and Trauma: Africa speaks to itself through Truth and Reconciliation films. Black Camera 1(1): 30-50.

Mignolo, W. 1995. The darker side of the renaissance: Literacy, territoriality and colonization. Ann Arbor: Michigan University Press.

Mignolo, W. 2000. Local histories/global designs: Coloniality, subaltern knowledges, and border thinking. Princeton University Press.

Mignolo, W. 2011. The Darker side of the Renaissance: Literacy, territoriality and colonization. Ann Arbor: Michigan University Press.

Ndlovu-Gatsheni, S. 2013. Coloniality of Power in Postcolonial Africa: Myths of Decolonzation. Dakar; Council for the Development of Social Science Research in Africa. https://codesria.org/IMG/pdf/0-Coloniality_of_Power_Ndlovu_Prelim. pdf?3311/c4053b4df101ba6371f78777ee747f6e74e26679.

Quijano, A. 1991. Coloniality and modernity / rationality. Indigenous Peru 13(29): 1120.

Quijano, A. 2000. Coloniality of power and social classification. Journal of World Systems Research VI(2): 342-386.

Sebald, W.G. 2001. Austerlitz. Translated by A Bell. Oxford: Random House.

Van der Schyff, M. 2015. A content analysis into the framing and representation of 'corrective rape' in three South African newspapers. https://ukzn-dspace.ukzn. ac.za/handle/10413/13179 
Van der Schyff, M. 2018. An issue of social and political salience: a content analysis of how South African newspapers report on 'corrective rape'. Global Media Journal 11(1) https://globalmedia.journals.ac.za/pub/article/view/281

Wallis, M. \& Duggan, P. 2011. Editorial: On trauma. Performance Research: A Journal of the Performing Arts 16(1): 1-3.

Wood, J.T. 2013. Gendered lives: Communication, gender and culture. Australia: Wadsworth/Cengage Learning.

Young, J.E. 2018. The stages of memory: Reflections on memorial art, loss and the spaces between. Amherst: University of Massachusetts Press. 